\title{
Rapid detection of porcine circovirus type 2 using a TaqMan-based real-time PCR
}

\author{
Kai Zhao ${ }^{1,3}$, Fangting Han ${ }^{4}$, Yong Zou ${ }^{2,3}$, Lianlong Zhu ${ }^{1,3}$, Chunhua Li ${ }^{2,3}$, Yan Xü ${ }^{4}$, Chunling Zhang ${ }^{2,3}$, Furong Tan ${ }^{1,3}$, \\ Jinbin Wang ${ }^{1,3}$, Shiru Tao ${ }^{1,3}$, Xizhong He ${ }^{2,3}$, Zongqing Zhou ${ }^{2,3}$, Xueming Tang ${ }^{1,3^{*}}$
}

\begin{abstract}
Porcine circovirus type 2 (PCV2) and the associated disease postweaning multisystemic wasting syndrome (PMWS) have caused heavy losses in global agriculture in recent decades. Rapid detection of PCV2 is very important for the effective prophylaxis and treatment of PMWS. To establish a sensitive, specific assay for the detection and quantitation of PCV2, we designed and synthesized specific primers and a probe in the open reading frame 2 . The assay had a wide dynamic range with excellent linearity and reliable reproducibility, and detected between $10^{2}$ and $10^{10}$ copies of the genomic DNA per reaction. The coefficient of variation for $\mathrm{Ct}$ values varied from $0.59 \%$ to $1.05 \%$ in the same assay and from $1.9 \%$ to $4.2 \%$ in 10 different assays. The assay did not cross-react with porcine circovirus type 1, porcine reproductive and respiratory, porcine epidemic diarrhea, transmissible gastroenteritis of pigs and rotavirus. The limits of detection and quantitation were 10 and 100 copies, respectively. Using the established real-time PCR system, 39 of the 40 samples we tested were detected as positive.
\end{abstract}

\section{Introduction}

Porcine circovirus type 2 (PCV2) is widespread in the commercial swine population [1-5], and is accepted as the causative agent of a number of diseases in these animals, particularly postweaning multisystemic wasting syndrome (PMWS) [6]. To date, PCV2 infection is common in some regions of China [7], and is considered as a major problem in pig production. There is therefore an urgent need for specific and effective methods to detect the virus.

By comparison with conventional PCR and ELISA, real-time PCR offers an effective way to detect target fragments specifically, rapidly and quantitatively. Falsepositive results and pollution can be prevented effectively at the same time. Therefore, real-time PCR has been developed quickly and has become the main method for pathogen detection [8].

In this study, we designed and synthesized specific primers and a TaqMan probe for PCV2. We have established an assay that is specific and sensitive for detection and quantitation of PCV2.

\footnotetext{
* Correspondence: saas.xmtang@gmail.com

'Biotechnology Research Institute, Shanghai Academy of Agricultural Sciences, 2901 Beidi Road, Shanghai, 201106, People's Republic of China Full list of author information is available at the end of the article
}

\section{Materials and methods}

Design of primers and TaqMan probe

The primer and TaqMan probe design were based on nucleotide sequences of open reading frame 2 (ORF2) retrieved from GenBank (EU921257.1), using the PCV2 strain from China (BJ0804) as a master sequence. The primers and probe (Table 1) were designed using Primer Premier 5.0, Oligo Primer Analysis software and DNAman 4.0. The length of the amplified product was $149 \mathrm{bp}$.

\section{Preparation of standard plasmid DNA}

The standard plasmid was constructed by inserting a PCR fragment into a pGEM-T Easy vector according to the manufacturer's instructions (Promega, Madison, WI, USA). The plasmid was propagated in Escherichia coli JM109 cells and was purified and subsequently quantified using an ND-1000 spectrophotometer (NanoDrop, Wilmington, DE, USA). Ten-fold dilutions were made to obtain $10^{10}-10^{0}$ per $\mu \mathrm{L}$ plasmid sample (containing $100 \mathrm{ng} / \mu \mathrm{L}$ yeast tRNA) for the real-time PCR. The dilutions were stored at $-20^{\circ} \mathrm{C}$, while the plasmids were stored at $-70^{\circ} \mathrm{C}$.

\section{Conventional PCR reaction}

PCR amplifications were performed in $25-\mu \mathrm{L}$ reaction volumes containing $1 \times$ PCR buffer, $200 \mu \mathrm{M}$ dATP,

\section{() Biomed Central}


Table 1 Sequences of primers and probe of PCV2

\begin{tabular}{ll}
\hline Primes and probe & Sequence \\
\hline Primer-1 & 5'-CGGATATTGTAKTCCTGGTCGTA-3' \\
Primer-2 & 5'-CCTGTCCTAGATTCCCCTATTGATT-3' \\
Probe & FAM-5'-CTAGGCCTACGTGGTCTACATTTC-3'-TAMRA \\
\hline
\end{tabular}

dTTP, dCTP and dGTP, 1.25 U DNA polymerase, $2 \mathrm{mM} \mathrm{MgCl}{ }_{2}$ (TaKaRa, Dalian, China), $200 \mathrm{nM}$ of each primer, and different quantities of the plasmid DNA templates. Amplifications were programmed as follows: one step of $94^{\circ} \mathrm{C}$ for $5 \mathrm{~min}, 30$ cycles of $94^{\circ} \mathrm{C}$ for $30 \mathrm{~s}$, $60^{\circ} \mathrm{C}$ for $20 \mathrm{~s}$ and $72^{\circ} \mathrm{C}$ for $20 \mathrm{~s}$, and one step of $72^{\circ} \mathrm{C}$ for $7 \mathrm{~min}$. Amplicons of $149 \mathrm{bp}$ were separated through $2 \%$ agarose gel containing 5\% Goldview (SBS Genetech, Shanghai, China). Negative and positive reference samples were applied in each reaction.

\section{TaqMan real-time PCR}

Real-time PCR was carried out on an ABI 7500 thermocycler (Applied Biosystems, CA, USA) with a final volume of $25 \mu \mathrm{L}$. The real-time PCR reactions contained the following ingredients: $1 \times \mathrm{PCR}$ buffer, $400 \mathrm{nM}$ primers, $200 \mathrm{nM}$ TaqMan probes, $400 \mu \mathrm{M}$ each of dATP, dTTP, dGTP and dCTP, 1.25 U Taq DNA polymerase, and $4.5 \mathrm{mM} \mathrm{MgCl}_{2}$. Real-time PCR reactions were run as follows: $95^{\circ} \mathrm{C}$ for $10 \mathrm{~min}$ and 45 cycles of $95^{\circ} \mathrm{C}$ for $15 \mathrm{~s}$ and $60^{\circ} \mathrm{C}$ for $40 \mathrm{~s}$. For a standard curve, serial dilutions of $10^{10}$ to $10^{0}$ copies of the plasmid were used. Each assay was performed in duplicate and each run included two negative controls.

\section{Limits of detection and quantitation of the assay}

To establish the limit of quantitation (LOQ) of the assay, samples containing $10^{7}, 10^{5}, 10^{3}$ and $10^{2}$ copies per sample were run in triplicate, and samples containing $90,80,70,60,50,40,30$ and 20 copies were also included. Samples containing 10 copies and one copy per sample were also run to estimate the limit of detection (LOD) of the assay.

\section{Reproducibility and specificity of the assay}

The standard PCV2 plasmid with $10^{7}, 10^{5}$ and $10^{3}$ copies was used to evaluate the coefficients of variation (CVs) of the real-time PCR. Intra- and inter-assay CVs for $\mathrm{Ct}$ values were both included. To test the specificity of the assay, plasmid samples containing $10^{8}, 10^{7}, 10^{6}$, $10^{5}$ and $10^{4}$ copies together with cDNA of porcine reproductive and respiratory, porcine epidemic diarrhea, transmissible gastroenteritis of pigs and rotavirus and DNA of porcine circovirus type 1 were run under optimal conditions of the assay. Negative controls were also contained in the run.

\section{Detection of clinical samples}

Three PCV2-positive samples and 37 serum and tissue unknown samples were tested using conventional PCR and real-time PCR under optimal conditions. Products from conventional PCR were examined in $2 \%$ agarose gel.

\section{Results}

\section{Real-time PCR for PCV2 DNA}

Ten-fold serial plasmid dilutions were used to construct the standard curve by plotting the logarithm of the plasmid copy number against the measured $\mathrm{Ct}$ values (Figure 1). The standard curve generated had a wide dynamic range of $10^{2}-10^{10}$ copies $/ \mu \mathrm{L}$ with a linear correlation $\left(R^{2}\right)$ of 0.9999 between the Ct value and the logarithm of the plasmid copy number.

\section{LOD and LOQ of the assay}

For reliable quantitation of the results under ideal conditions, approximately 100 initial template copies were required, thereby specifying the LOQ of this assay. When the number of template copies fell below 100, the $\mathrm{Ct}$ values lay outside of the linear range (Figure 2). The target sequence could be detected in all amplification reactions down to 10 copies, but not when only one copy was present (Figure 3). These results indicate that the LOD value was $\sim 10$ copies.

\section{Reproducibility and specificity of the assay}

The CVs for the Ct values ranged from $0.59 \%$ to $1.05 \%$ in the same assay and from $1.9 \%$ to $4.2 \%$ in 10 different assays (Table 2). No increase in fluorescence was observed in the negative control and PCV1, PRRS, PED, TGE and RV samples.

\section{Detection of clinical samples}

Table 3 and 4 showed that the PCV2-positive rates in the unknown samples of conventional PCR detection and real-time PCR detection were $78.3 \%$ and $97.3 \%$, respectively. The real-time PCR approach increased the

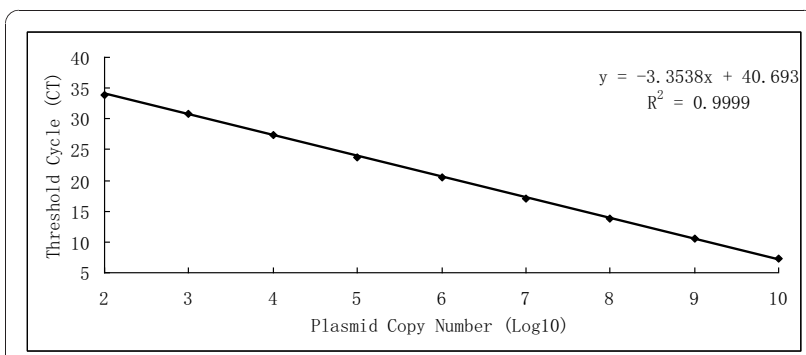

Figure 1 Standard curve between $\mathrm{Ct}$ value and $\log _{10}$ copy number of PCV2 plasmid DNA 


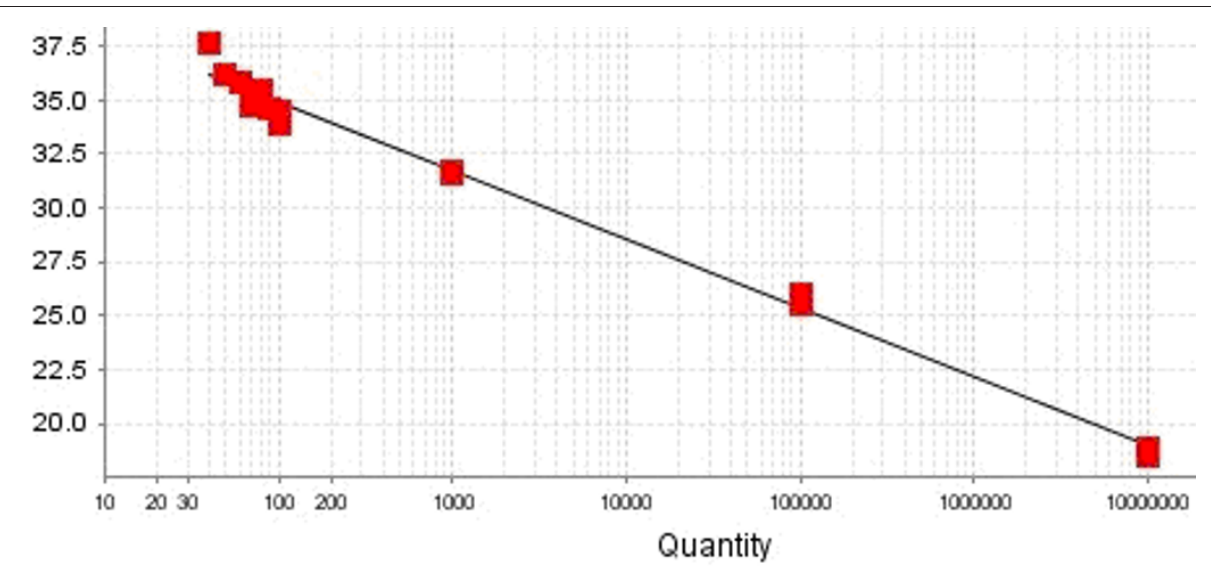

Figure 2 Determination of the limit of quantitation.

detection of PCV2 samples by $18 \%$ over that achieved by conventional PCR.

The viral loads were mostly between 10 and 1000 copies $/ \mu \mathrm{L}$ sample with a few samples containing up to $10^{8}$ copies/ $\mu \mathrm{L}$. Three hundred and sixty and 1560 copies of PCV2 were detected per microliter in the PPV and PRV DNA extracted from serum samples. It appeared that the pigs from which the PPV and PRV DNA samples were obtained were co-infected with PCV2.

\section{Discussion}

Serological surveys have shown that up to $100 \%$ of investigated farms and up to $100 \%$ of individual pigs sampled in parts of Europe, the United States and Canada are seropositive for PCV2 [9-11]. Using ELISA on samples collected in seven provinces and municipalities in China, the seropositive rate was found to be up to $42.9 \%$ [12].

PCV2-induced diseases on farms are reported to increase pig mortality from $2-3 \%$ to $14-30 \%$ [13]. Therefore, rapid and sensitive detection and quantitation assays for PCV2 are urgently needed both by the pig industry and research community. In comparison with conventional PCR, TaqMan real-time PCR is more sensitive and less easily contaminated. The main difficulty of using conventional PCR is that contamination occurs when products are examined in gels, which leads to false-positive results in later experiments. For this reason, real-time PCR is widely used, and in addition, it has heightened sensitivity and requires less time than conventional PCR.

The major conserved region for PCV2 located in ORF2 is likely to be the ideal reference fragment to detect PCV2, because this region displays the highest diversity between PCV1 and PCV2 and there are more sequenced isolates available from PCV2 than there are from PCV1 [14]. Hybridization probes that combine only with the target products have primarily been used in previous studies to detect PCV2, and the results of these studies have shown high sensitivity and specificity. Several other methods are available to detect and quantify PCV2. Brunborg et al. [14] have used a TaqMan probe to detect an 84-bp fragment in ORF2 and to quantify the viral load in different tissues and serum samples. In a report by Chung et al. [15], PCV2 was quantified in naturally infected and challenged pigs

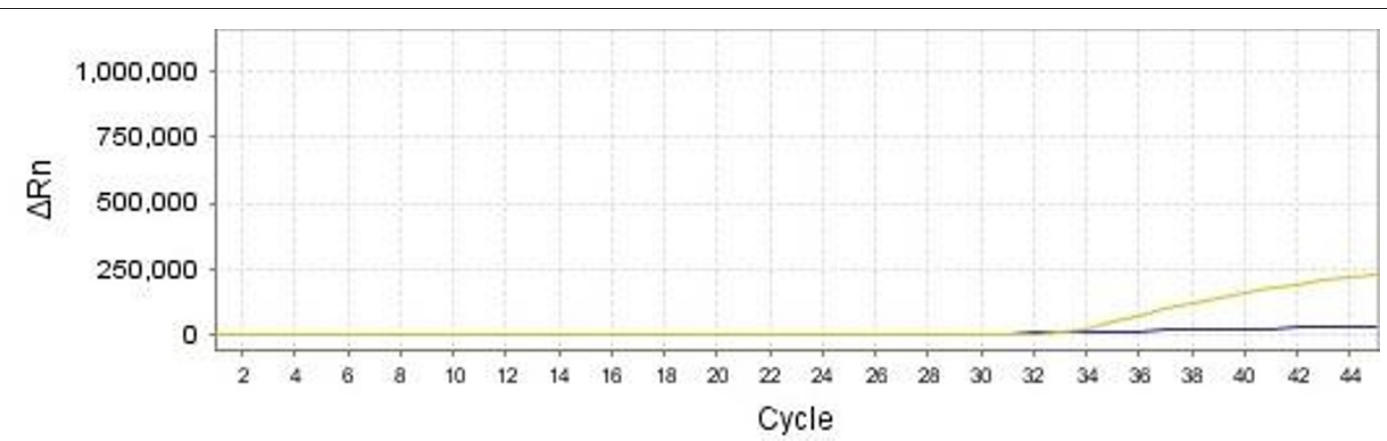

Figure 3 Determination of the limit of detection. The yellow and blue curves reveal the fluorescence values observed in samples containing 10 and 1 copies of PCV2 plasmid respectively. 
Table 2 Intra- and inter-assay reproducibility of the real-time PCR

\begin{tabular}{cccccccc}
\hline Concentration of plasmid Standard (copy/ $\boldsymbol{\mu l}$ ) & \multicolumn{3}{c}{ Intra-assay } & \multicolumn{3}{c}{ Inter-assay } \\
\cline { 2 - 7 } & Mean Ct & SD & CV (\%) & Mean Ct & SD & CV (\%) \\
\hline 107 & 17.88 & 0.1069 & 0.68 & 17.69 & 0.7498 & 4.2 \\
105 & 24.49 & 0.2589 & 1.05 & 24.03 & 0.5597 & 2.3 \\
103 & 30.98 & 0.2092 & 0.59 & 30.22 & 0.5632 & 1.9 \\
\hline
\end{tabular}

SD, standard deviation; CV, Coefficient of variation.

using a TaqMan real-time PCR that detected a fragment of 269 bp. Yang et al. [16] have used SYBR Green I based on nucleotide sequences of ORF2 for the detection of PCV2.

In this study we designed different primers, a different probe and a different real-time PCR system, which amplified a 149-bp fragment to detect PCV2. The realtime PCR approach increased the detection of PCV2 samples by $18 \%$ over that achieved by conventional PCR. Tests on the reproducibility of the method suggest that the established real-time PCR system appears to be reliable and stable. A series of experiments were carried out to assess the reproducibility, sensitivity, and specificity of the assay. Using several other swine viruses as template, no cross-reaction signals were detected, which demonstrated the specificity of the assay. The established real-time PCR system that we developed might not only provide an effective way to detect PCV2 rapidly and sensitively, but might also be applied to assess the effectiveness of vaccines developed to combat PCV2. The real-time PCR detection system complements and extends previous methods for detection and quantitation of PCV2. The specific detection method can also provide an alternative approach for detection of PCV2.

Table 3 Comparison between conventional PCR and real-time PCR for PCV2 positive samples

\begin{tabular}{clcc}
\hline Conventional PCR & \multicolumn{2}{c}{ Real time PCR } & \multirow{2}{*}{ Subtotal } \\
\cline { 2 - 3 } & + & - & \\
\hline+ & 3 & 0 & 3 \\
- & 0 & 0 & 0 \\
\hline Total & & & 3
\end{tabular}

+, positive; -, negative.

Table 4 Comparison between conventional PCR and real-time PCR for unknown samples

\begin{tabular}{cccc}
\hline Conventional PCR & \multicolumn{2}{c}{ Real time PCR } & \multirow{2}{*}{ Subtotal } \\
\cline { 2 - 3 } & + & - & \\
\hline+ & 29 & 0 & 29 \\
- & 7 & 1 & 8 \\
\hline Total & & & 37 \\
\hline
\end{tabular}

+ , positive; -, negative.

\section{Abbreviations}

bp: base pair; CDNA: complementary DNA; LOD: limit of detection; LOQ: limit of quantitation; ORF2: open reading frame 2; PCV1: Porcine circovirus type 1 ; PCV2: Porcine circovirus type 2; PED: Porcine epidemic diarrhea; PMWS:

Postweaning multisystemic wasting syndrome; PPV: Porcine parvovirus; PRRS: Porcine reproductive and respiratory; PRV: Pseudorabies virus; RV: Rotavirus;

TGE: Transmissible gastroenteritis of pigs;.

\section{Acknowledgements}

This work was financially supported by Shanghai Agricultural Science Committee foundation of China, grant no.2009-6-4 International Cooperation Foundation of Shanghai grant no.10410703500, Shanghai agricultural science key research project, grant no. 2008-8-5.

\section{Author details}

'Biotechnology Research Institute, Shanghai Academy of Agricultural Sciences, 2901 Beidi Road, Shanghai, 201106, People's Republic of China. ${ }^{2}$ Institute of Animal Science and Veterinary Medicine, Shanghai Academy of Agricultural Sciences, 2901 Beidi Road, Shanghai, 201106, People's Republic of China. ${ }^{3}$ Key Laboratory of Agricultural Genetics and Breeding, Shanghai Academy of Agricultural Sciences, 2901 Beidi Road, Shanghai, 201106, People's Republic of China. ${ }^{4}$ College of Life and Environment Sciences, Shanghai Normal University,100 Guilin Road, Shanghai 200234, People's Republic of China.

\section{Authors' contributions}

$\mathrm{KZ}, \mathrm{FH}$ and $\mathrm{XT}$ participated in the design and carried out the majority of the experiments in the study and drafted the manuscript. $Y Z, L Z, C L, Y X, C Z, F T$, JW, ST, XH, ZZ and XT helped to carry out the experiments and draft the manuscript. All authors read and approved the final manuscript.

\section{Competing interests}

The authors declare that they have no competing interests.

Received: 31 August 2010 Accepted: 31 December 2010 Published: 31 December 2010

\section{References}

1. Allan GM, Ellis JA: Porcine circoviruses: a review. J Vet Diagn Invest 2000, 12:3-14.

2. Ellis J, Clark E, Haines D, West K, Krakowka S, Kennedy S, Allan GM: Porcine circovirus-2 and concurrent infections in the field. Vet Microbiol 2004, 98:159-163.

3. Segales J, Domingo M: Postweaning multisystemic wasting syndrome (PMWS) in pigs: a review. Vet Q 2002, 24:109-124.

4. Segales J, Rosell C, Domingo M: Pathological findings associated with naturally acquired porcine circovirus type 2 associated disease. Vet Microbiol 2004, 98:137-149.

5. Brunborg IM, Jonassen CM, Moldal T, Bratberg B, Lium B, Koenen F, Schönheit J: Association of myocarditis with high viral load of porcine circovirus type 2 in several tissues in cases of fetal death and high mortality in piglets: a case study. J Vet Diagn Invest 2007, 19:368-375.

6. Allan GM, McNeilly F, Meehan BM, Kennedy S, Mackie DP, Ellis JA, Clark EG, Espuna E, Saubi N, Riera P: Isolation and characterization of circoviruses from pigs with wasting syndromes in Spain, Denmark and Northern Ireland. Vet Microbiol 1999, 66:115-123.

7. Wu DM, Cao YC, Bi YJ: Research progress of porcine circovirus: a review. Chin J Prev Vet Med 2004, 26(1):76-78. 
8. Linssen B, Kinney RM, Aguilar P, Russell KL, Watts DM, Kaaden OR, Pfeffer M: Development of reverse transcription-PCR assays specific for detection of equine encephalitis viruses. J Clin Microbiol 2000, 38:1527-1535.

9. Allan GM, Ellis JA: Porcine circoviruses: a review. J Vet Diagn Invest 2000, 12:3-14.

10. Cottrell TS, Friendship RM, Dewey CE, Josephson G, Allan G, Walker I: A study investigating epidemiological risk factors for porcine circovirus type II in Ontario. Pig J 1999, 44:10-17.

11. Walker IW, Konoby CA, Jewhurst VA, MCNair I, McNeilly F, Meehan BM, Cottrell TS, Ellis JA, Allan GM: Development and application of a competitive enzyme-linked immunosorbent assay for the detection of serum antibodies to porcine circovirus type 2. J Vet Diagn Invest 2000, 12:400-405.

12. L HW, Zhang GC, Wu FQ: Antibody detection of weaning multisystemic wasting syndrome. Chin J Vet Sci Tech 2000, 23:591-592.

13. Esther S, Carole B, Heidi G, Artur S, Kenneth MC: Cellular adaptive immune response against porcine circovirus type 2 in subclinically infected pigs. BMC Vet Res 2009, 5:45.

14. Brunborg IM, Moldal T, Jonassen CM: Quantitation of porcine circovirus type 2 isolated from serum/plasma and tissue samples of healthy pigs and pigs with postweaning multisystemic wasting syndrome using a TaqMan-based real-time PCR. J Virol Methods 2004, 122(2):171-178.

15. Chung WB, Chan WH, Chaung HC, Lien Y, Wu CC, Huang YL: Real-time PCR for quantitation of porcine reproductive and respiratory syndrome virus and porcine circovirus type 2 in naturally-infected and challenged pigs. J Virol Methods 2005, 124:11-19.

16. Yang ZZ, Habib Mudasser, Shuai JB, Fang WH: Detection of PCV2 DNA by SYBR Green I-based quantitative PCR. J Zhejiang Univ Sci B 2007, 8(3):162-169.

doi:10.1186/1743-422X-7-374

Cite this article as: Zhao et al:: Rapid detection of porcine circovirus type 2 using a TaqMan-based real-time PCR. Virology Journal 2010 7:374.

\section{Submit your next manuscript to BioMed Central and take full advantage of:}

- Convenient online submission

- Thorough peer review

- No space constraints or color figure charges

- Immediate publication on acceptance

- Inclusion in PubMed, CAS, Scopus and Google Scholar

- Research which is freely available for redistribution

Submit your manuscript at www.biomedcentral.com/submit
C BioMed Central 